\title{
Satisfaction's Level of Hypertensive Patients towards Pharmacy Counseling with Al-Quran Based at Karya Sehat Pharmacy in Purwokerto, Banyumas Regency
}

\author{
Githa F. Galistiani, Much I. N. A. Wibowo, Rachmi Gladiawati, Dwi Merishandy \\ Faculty of Pharmacy, Universitas Muhammadiyah Purwokerto, Purwokerto, Indonesia
}

\begin{abstract}
Hypertension is a major cause of death in some countries. World Health Organization (WHO) estimated there are $11 \%$ of undetected hypertension in which $50 \%$ of them are living in developing countries such as Indonesia, with the incidence of $25.8 \%$. Pharmaceutical counseling is one of the most comprehensive pharmacist services. Therefore, pharmacists' participation through counseling is needed to provide pharmacological therapy by administration of antihypertensive medication and nonpharmacological therapy, for instance by recital of Al-Quran during pharmaceutical therapy which become the objective of this study. This research aimed to determine satisfaction's level of hypertensive patients with the intervention of pharmaceutical counseling with Al-Quran based as well as effectiveness of the therapy. This research was conducted from February until March 2017 at Karya Sehat Pharmacy in Banyumas regency. This research is an experimental with post test only design group methods. Data in this study is quantitative data with questionnaires as research instruments. Result of this research showed that the satisfaction's level of patients with usual care counseling and Al-Quran based pharmacy counseling had CSI values of $73.55 \%$ and $72.63 \%$, respectively. There is no difference of level of satisfaction between the two groups. Both of pharmacy counseling methods can be applied in pharmacy services to improve patients's satisfaction.
\end{abstract}

Keywords: Hypertension, patient's satisfaction, pharmaceutical counseling

\section{Tingkat Kepuasan Pasien dalam Pelayanan Konseling Kefarmasian Berbasis Al-Quran di Apotek Karya Sehat Purwokerto, Kabupaten Banyumas}

\begin{abstract}
Abstrak
Hipertensi menjadi penyebab utama kematian di beberapa negara. World Health Organization (WHO) memperkirakan terdapat $11 \%$ pasien hipertensi di dunia yang tidak terdeteksi dan $50 \%$ di antaranya berada di negara berkembang, salah satunya di Indonesia dengan angka kejadian sebesar $25,8 \%$. Konseling kefarmasian merupakan salah satu pelayanan apoteker yang komprehensif. Untuk itu, diperlukan partisipasi aktif apoteker melalui konseling di apotek yang mudah ditemui oleh masyarakat untuk memberikan terapi farmakologi berupa pemberian obat antihipertensi dan penyaranan terapi nonfarmakologi, salah satunya berupa penganjuran membaca Al-Quran pada saat melakukan konseling kefarmasian. Penelitian ini bertujuan untuk mengetahui tingkat kepuasan pasien hipertensi yang mendapatkan intervensi konseling kefarmasian berbasis Al-Quran terhadap pelayanan apoteker serta efektivitas pengobatan pasien. Penelitian ini dilaksanakan pada bulan Februari-Maret 2017 di Apotek Karya Sehat Purwokerto, Kabupaten Banyumas. Metode penelitian ini menggunakan eksperimental dengan pendekatan post test only groups design. Jenis data yang digunakan merupakan data kuantitatif dengan bantuan kuesioner sebagai instrumen penelitian. Tingkat kepuasan pasien yang mendapatkan konseling kefarmasian usual care dan konseling kefarmasian berbasis Al-Quran masing-masing memiliki nilai CSI sebesar $73.55 \%$ dan $72.63 \%$. Tidak terdapat perbedaan tingkat kepuasan antara kedua kelompok. Kedua metode konseling kefarmasian dapat diterapkan dalam pelayanan kefarmasain untuk meningkatkan kepuasan pasien.
\end{abstract}

Kata kunci: Hipertensi, kepuasan pasien, konseling kefarmasian

Correspondence: Githa F. Galistiani, M.Sc., Apt., Faculty of Pharmacy, Universitas Muhammadiyah Purwokerto, Purwokerto, Central Java 53182, Indonesia, email: githafungiegalistiani@ump.ac.id Received: 13 $^{\text {th }}$ January 2018, Accepted: $5^{\text {th }}$ February 2018, Published: $1^{\text {st }}$ March 2018 


\section{Introduction}

High blood pressure or commonly known as hypertension is by now still becoming the most dangerous disease to cause death in the world. World Health Organization (WHO) assumes that there are $11 \%$ undetected hypertensive sufferers in the world in which $50 \%$ of them are living in several developing countries. ${ }^{1,2}$ In 2013, the number of case of hypertension in Indonesia reached 25.8\% with Central Java becoming the most region with higher ratio of hypertension case, even compared to national ratio with only $26.4 \% .^{3}$ The case regarding to hypertension in Banyumas reached only $2.53 \%$ in 2014 with 3.618 total sufferers. ${ }^{4}$

Hypertension can actually be cured by pharmacological and non-pharmacological therapy; pharmacological therapy can be done by utilizing anti-hypertensive drugs to patients, while non-pharmacological therapy can be done through several methods in which one of them is by suggesting the sufferers to read the holy Al-Quran. Listening to Al-Quran is recommended by psychologists to improve mental health and achieving greater calm. ${ }^{5}$ Hence, the active support of pharmacists in handling an effective pharmacological and non-pharmacological counseling will help the sufferers understand about hypertension and the medical treatment they are undertaking. ${ }^{6}$

Through pharmaceutical counseling with Al-Quran based intervention, it is expected to raise patients' level of satisfaction towards pharmacists' service as well as effectiveness of treatment taken by them. Research regarding to this topic has never been conducted in any pharmacies in Banyumas regency. Based on that investigation, it is important to conduct a research aiming to figure out the difference of hypertensive patients' level of satisfaction to both pharmaceutical counseling with AlQuran based intervention and the usual care one at Karya Sehat Pharmacy, Purwokerto, Banyumas regency.
The objectives of this research are to figure out hypertension patients' satisfaction's level at Karya Sehat Pharmacy in Purwokerto, Banyumas regency towards Al-Quran based pharmaceutical counseling and usual care counseling, and to figure out the difference of satisfaction's level of hypertensive patients' between pharmaceutical counseling with AlQuran based intervention and the usual care or conventional counseling.

\section{Methods}

This study was an experimental research with posttest only group design approach. It was carried by giving pharmaceutical counseling with Al-Quran based intervention and usual care one by pharmacists. This research used questionnaire as an instrument filled by the respondents about their satisfaction after they have been given the counseling. Data of this research was quantitative obtained from the questionnaires. This research was approved by Medical Research Ethics Commission of Medical Faculty Universitas Jendral Soedirman with ref number 1344/KEPK/III/2017.

This research was conducted at Karya Sehat Pharmacy in Purwokerto, Banyumas regency, Central Java. Sample in this research were hypertensive patients who were in the meantime members of Program Pengelolaan Penyakit Kronis (Prolanis) at Karya Sehat Pharmacy and took prescriptions in the range time when this research was being conducted. Inclusion criteria were all respondents who have been diagnosed by doctor to have been suffering from hypertension, either level 1 or level 2 hypertension, were muslims, willing to be the sample of this research by signing informed consent, willing to take a therapy by utilizing hypertensive drugs, aged 18-75 years old, and not undertaking any meditation or relaxation therapy programs. Exclusion criteria included the respondents who were illiterate of either latin or hijaiyah alphabet, 
and were no longer being member of Prolanis (have resigned from the program along the research was being conducted).

Data analysis was done by employing univariate analysis which were bivariate and Importance-Performance Analysis (IPA). Univariate analysis was used to describe the characteristics of respondents, while bivariate used to explain patients' satisfaction between two groups by doing Chi-Square statistic test with $95 \%$ confidence interval. ${ }^{7}$

\section{Results}

From Table 1, it can be seen that most of the respondents aged 56-65 years old with total of 26 respondents $(47,3 \%)$. The distribution of respondents suffering from hypertension based on gender is female with total of 32 respondents $(58,2 \%)$, meanwhile distribution of respondents suffering from hypertension based on their education level is high school students with total of 20 respondents $(36,4 \%)$. The result of Chi-Square and KolmogorovSmirnov statistic tests showed p-value to age, gender and education level are 0.967, 0.480 and 0.676 respectively. Hence, there are no different proportion regarding to respondents' characteristics in both groups.

Result of pharmaceutical counseling with Al-Quran based (experiment group) and usual care one (control group) shows that most of the respondents felt satisfied with the counseling. A total of 17 respondents (60.7\%) considered pharmaceutical counseling with Al-Quran based intervention satisfying, meanwhile 16 respondents $(59.3 \%)$ felt satisfied of usual care counseling. The result of KolmogorovSmirnov test as the alternative of Chi-Square test shows p-value of 0.167 (Table 2), so it can be concluded that there are no different proportion regarding to satisfactions' level of respondents in both groups.

\section{Importance-Performance Analysis (IPA)}

\section{Quadrant analysis}

Quadrant control analyze the average score of usual care pharmaceutical counseling and the expectation of usual care pharmaceutical counseling of each variable. The average score of the satisfaction (X) is 3.70, while the average score of the expectation (Y) is 3.90. These scores are then used as the quadrant limiting point. Hence, the cartesian diagram is divided into four categories: (a)

Table 1 Characteristics of Respondents

\begin{tabular}{|c|c|c|c|c|c|c|c|}
\hline \multirow{2}{*}{ Characteristics } & \multicolumn{2}{|c|}{ Experiment Group } & \multicolumn{2}{|c|}{ Control Group } & \multicolumn{2}{|c|}{ Total } & \multirow{2}{*}{ p-value } \\
\hline & $\mathbf{n}$ & $\%$ & $\mathbf{n}$ & $\%$ & $\mathbf{n}$ & $\%$ & \\
\hline \multicolumn{8}{|l|}{ Age } \\
\hline$<46$ years & 1 & 3.6 & 1 & 3.7 & 2 & 3.6 & \multirow{4}{*}{$0.967 * *$} \\
\hline 46-55 years & 6 & 21.4 & 3 & 11.1 & 9 & 16.4 & \\
\hline 56-65 years & 10 & 39.3 & 16 & 59.3 & 26 & 47.3 & \\
\hline$>65$ years & 11 & 35.7 & 7 & 25.9 & 18 & 32.7 & \\
\hline \multicolumn{8}{|l|}{ Gender } \\
\hline Female & 15 & 53.6 & 17 & 63.0 & 32 & 58.2 & \multirow[t]{2}{*}{$0.480^{*}$} \\
\hline Male & 13 & 46.4 & 10 & 37.0 & 23 & 41.8 & \\
\hline \multicolumn{8}{|l|}{ Education Level } \\
\hline Elemantary school & 4 & 14.3 & 9 & 33.3 & 13 & 23.6 & \multirow{5}{*}{$0.676^{* *}$} \\
\hline Junior high school & 3 & 10.7 & 3 & 11.1 & 6 & 10.9 & \\
\hline Senior high school & 11 & 39.3 & 9 & 33.3 & 20 & 36.4 & \\
\hline College & 10 & 35.7 & 2 & 7.4 & 12 & 21.8 & \\
\hline Not taking school & 0 & 0 & 4 & 14.8 & 4 & 7.3 & \\
\hline
\end{tabular}


Table 2 The Influence of Pharmaceutical Counseling with Al-Quran Based and Usual Care Pharmaceutical Counseling on Patients' Satisfaction

\begin{tabular}{|c|c|c|c|c|c|c|c|}
\hline \multirow{3}{*}{ Group } & \multicolumn{6}{|c|}{ Satisfaction's Level } & \multirow{3}{*}{$\mathbf{p}$} \\
\hline & \multicolumn{2}{|c|}{ Very Satisfied } & \multicolumn{2}{|c|}{ Satisfied } & \multicolumn{2}{|c|}{ Quite Satisfied } & \\
\hline & n & $\%$ & $\mathbf{n}$ & $\%$ & $\mathbf{n}$ & $\%$ & \\
\hline Experiment Group & 5 & 17.9 & 17 & 60.7 & 6 & 21.4 & \\
\hline Control Group & 4 & 14.8 & 16 & 59.3 & 7 & 25.9 & 0,167 \\
\hline Total & 9 & 16.4 & 33 & 60 & 13 & 23.6 & \\
\hline
\end{tabular}

Quadrant I, these variables have satisfaction level below the average score, but it has quite high expectation level. The variables belong to quadrant I are variable: 1, 2, 6 and 9; (b) Quadrant II, these variables have high both satisfaction and expectation level. The variables belong to this category are: 8, 11, 12, 15 and 16; (c) Quadrant III, these variables have low expectation level and satisfaction level is also considered to be not really good by the respondents. The variables belong to this quadrant are: $3,4,5$ and 10 ; (d) Quadrant IV, these variables have low expectation level, but have high satisfaction level. The variables belong to this category are: 7, 13 and 14 (Figure 1).

For pharmaceutical counseling Al-Quran based intervention, the average score of the satisfaction $(\mathrm{X})$ is 3.63 , while the average score of the expectation (Y) is 4.01 , the scores are then used as quadrant limiting point, and the cartesian diagram is divided into as follows: (a) Quadrant I, these variables have satisfaction level below the average score, but it has quite high expectation level. The variables belong to quadrant I are variable: 2, 7, 13, 14 and 16; (b) Quadrant II, these variables have high both satisfaction and expectation level. The variables belong to this category are: 1, 5 and 10; (c) Quadrant III, these variables have low expectation level and satisfaction level is also considered to be not really good by the respondents. The variables belong to this quadrant are: 9; (d) Quadrant IV, these variables have low expectation level, but have high satisfaction level. The variables belong to this category are: $3,4,6,8,11,12$ and 15 (Figure 2).

\section{GAP analysis}

Based on satisfaction and expectation GAP analysis towards usual care pharmaceutical counseling, 14 variables have negative score (Table 3). As the result, the satisfaction level on usual care pharmaceutical counseling is still below the respondents' expectation. However, there are two positive variables, that are variable 13 and 14 in tangible dimension

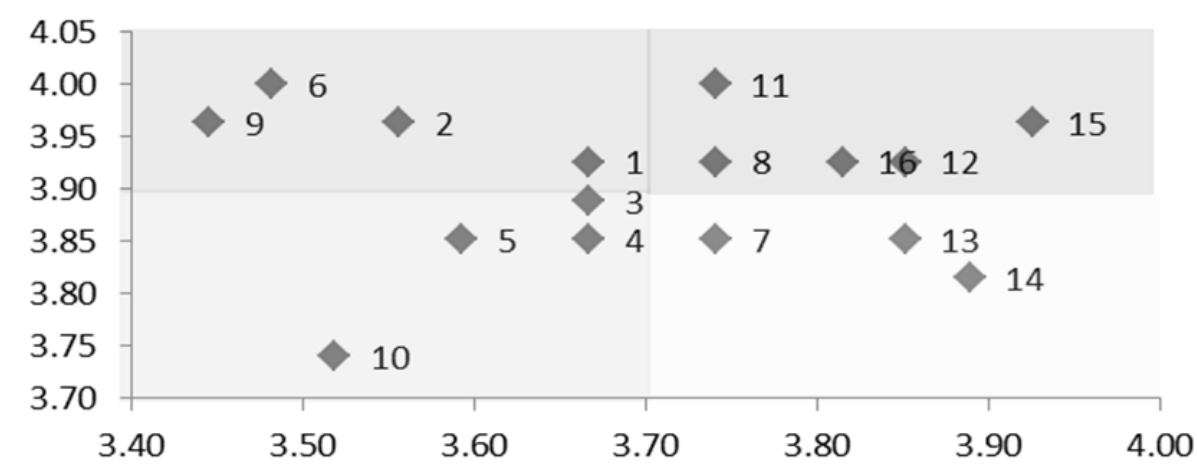

Figure 1 Cartesian Diagram of Satisfaction and Expectation of Usual Care Pharmaceutical Counseling 
Table 3 GAP of Usual Care Pharmaceutical Counseling and Pharmaceutical Counseling with AlQuran Based on Patients' Satisfaction

\begin{tabular}{|c|c|c|c|c|c|c|c|c|c|}
\hline \multirow[b]{2}{*}{ Dimension } & \multirow[b]{2}{*}{ Variable } & \multicolumn{4}{|c|}{ Control Group } & \multicolumn{4}{|c|}{ Experiment Group } \\
\hline & & $(\mathrm{X})$ & $(\mathbf{Y})$ & GAP & $\begin{array}{c}\text { GAP } \\
\text { Average/ } \\
\text { Dimension }\end{array}$ & $(\mathrm{X})$ & (Y) & GAP & $\begin{array}{c}\text { GAP } \\
\text { Average/ } \\
\text { Dimension }\end{array}$ \\
\hline Reliability & $\begin{array}{l}1 \\
2 \\
3 \\
4\end{array}$ & $\begin{array}{l}3.67 \\
3.56 \\
3.67 \\
3.67\end{array}$ & $\begin{array}{l}3.93 \\
3.96 \\
3.89 \\
3.85\end{array}$ & $\begin{array}{r}-0.26 \\
-0.41 \\
-0.22 \\
-0.19\end{array}$ & -0.27 & $\begin{array}{l}3.79 \\
3.61 \\
3.79 \\
3.71\end{array}$ & $\begin{array}{l}4.21 \\
4.21 \\
3.82 \\
3.89\end{array}$ & $\begin{array}{r}-0.43 \\
-0.61 \\
-0.04 \\
-0.18\end{array}$ & -0.31 \\
\hline Responsiveness & $\begin{array}{l}5 \\
6\end{array}$ & $\begin{array}{l}3.59 \\
3.48\end{array}$ & $\begin{array}{l}3.85 \\
4.00\end{array}$ & $\begin{array}{l}-0.26 \\
-0.52\end{array}$ & -0.39 & $\begin{array}{l}3.64 \\
3.68\end{array}$ & $\begin{array}{l}4.04 \\
3.96\end{array}$ & $\begin{array}{l}-0.39 \\
-0.29\end{array}$ & -0.34 \\
\hline Assurance & $\begin{array}{l}7 \\
8 \\
9\end{array}$ & $\begin{array}{l}3.74 \\
3.74 \\
3.44\end{array}$ & $\begin{array}{l}3.85 \\
3.93 \\
3.96\end{array}$ & $\begin{array}{l}-0.11 \\
-0.19 \\
-0.52\end{array}$ & -0.27 & $\begin{array}{l}3.61 \\
3.68 \\
3.46\end{array}$ & $\begin{array}{l}4.14 \\
3.86 \\
3.96\end{array}$ & $\begin{array}{l}-0.54 \\
-0.18 \\
-0.50\end{array}$ & -0.40 \\
\hline Empathy & $\begin{array}{l}10 \\
11 \\
12\end{array}$ & $\begin{array}{l}3.52 \\
3.74 \\
3.85\end{array}$ & $\begin{array}{l}3.74 \\
4.00 \\
3.93\end{array}$ & $\begin{array}{l}-0.22 \\
-0.26 \\
-0.07\end{array}$ & -0.19 & $\begin{array}{l}3.68 \\
3.68 \\
3.64\end{array}$ & $\begin{array}{l}4.07 \\
4.00 \\
3.93\end{array}$ & $\begin{array}{l}-0.39 \\
-0.32 \\
-0.29\end{array}$ & -0.33 \\
\hline Tangible & $\begin{array}{l}13 \\
14 \\
15 \\
16\end{array}$ & $\begin{array}{l}3.85 \\
3.89 \\
3.93 \\
3.81\end{array}$ & $\begin{array}{l}3.85 \\
3.81 \\
3.96 \\
3.93\end{array}$ & $\begin{array}{c}0.00 \\
0.07 \\
-0.04 \\
-0.11\end{array}$ & -0.02 & $\begin{array}{l}3.79 \\
3.61 \\
3.79 \\
3.71\end{array}$ & $\begin{array}{l}4.21 \\
4.21 \\
3.82 \\
3.89\end{array}$ & $\begin{array}{l}-0.43 \\
-0.61 \\
-0.04 \\
-0.18\end{array}$ & -0.31 \\
\hline
\end{tabular}

Source: Primary data, 2017

in which shows the respondents' satisfaction towards variable 13 and 14 have fulfilled the respondents' expectation regarding to usual care pharmaceutical counseling service.

\section{Discussion}

This research was conducted from February until March 2017 at Karya Sehat Pharmacy located in Purwokerto, Banyumas regency. Data collection was done at Prolanis activity that involved 28 respondents of experiment group and 27 respondents of control group. Pharmaceutical counseling with Al-Quran based intervention was given by pharmacists in Prolanis activity while the respondents took the drug prescription. . The experiment group respondents was suggested by the pharmacists to recite Al-Quran three times in a week for a month, the research by Mottaghi (2011) which stated that Al-Quran recitation can reduce the level of anxiety in athletes. ${ }^{8}$ The monitoring

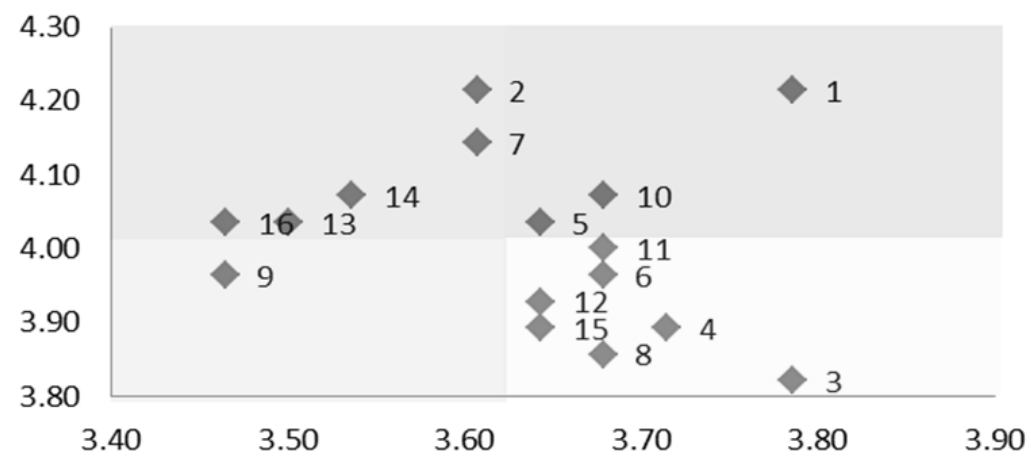

Figure 2 Cartesian Diagram of Satisfaction and Expectation of Al-Quran Based Pharmaceutical Counseling 
on Al-Quran (Surah Ar-Rahman) reciting was done by utilizing SMS reminder and diary book intervention. In Prolanis activity in March, the respondents of experiment group were asked to fill out the questionnaire about pharmaceutical counseling with Al-Quran based, while control group respondents were asked to fill out the questionnaire about usual care pharmaceutical counseling.

Copstead and Jacquelyn (2005) stated that hypertension suffering is in line with increasing age. This happens because artery losts its elasticity as someone gets older where the chance of someone suffering from hypertension increases when they are in the age of 50-60 years old. ${ }^{9}$ The distribution of female is more than male respondents. This possibly happens because estrogen hormones in women decreases as they get older which can cause the hypertension. ${ }^{10}$ The distribution of respondents suffering from hypertension based on education level is senior high school students with total 20 respondents (36.4\%).

GAP score of each variable and average GAP score of each dimension shows priority betterment, means the higher GAP score of a variable or a dimension, the more prioritized the betterment they should have. ${ }^{11}$ In respect ti this, the variables that should be prioritized are variable 6 and 9. Variable 6 is about how the pharmacists give information when the patients do not really understand about the drugs, meanwhile variable 9 is about the availability of a assurance if there is a mistake in usual care or conventional pharmaceutical counseling program in the future. Based on the GAP score of each dimension, the dimension that should be prioritized to have betterment is responsiveness dimension. The GAP score of respondents' satisfaction and expectation to pharmaceutical counseling with Al-Quran based is negative, which means that level of satisfaction in respondents to pharmaceutical counseling with Al-Quran based is still below the expectation. The variables that should be prioritized to have betterment are: variable 2 , which is about how the pharmacists give information about the drugs; and variable 14 , which is about the completeness and the cleanliness of the instruments used. Based on the GAP average score of each dimension, the dimension that should be prioritized to have betterment is assurance dimension.

The CSI score of usual care pharmaceutical counseling is $73.55 \%$ and of pharmaceutical counseling with Al-Quran based intervention is $72.63 \%$ in the range of satisfaction level which is $66-80.99 \% .{ }^{12}$ So, all the attributes of usual care pharmaceutical counseling and pharmaceutical counseling with Al-Quran based are said to have been able to satisfy the respondents.

\section{Conclusion}

Based on the result of this research, it can can be inferred that satisfaction's level of respondents in control group who received usual care or conventional pharmaceutical counseling is $73.55 \%$. Although pharmaceutical counseling with Al-Quran based was a new intervention, it cannot be found any significant proportion of respondents' satisfaction's level between respondents who received pharmaceutical counseling with Al-Quran based and those who got conventional counseling ( $\mathrm{p}$-value= 0.167). Generally speaking, pharmaceutical counseling with Al-Quran based has good potential to implement.

\section{Acknowledgements}

We thank all of the staff in Karya Sehat Pharmacy, Purwokerto, Banyumas Regency for their cooperation during this research.

\section{Funding}

This research was financially supported by Community Service and Research Board 
(Lembaga Penelitian dan Pengabdian Masyarakat) Universitas Muhammadiyah Purwokerto with grant number: A.11-III/587S.Pj./LPPM/XI/2016.

\section{Conflict of Interest}

The authors declare that there is no conflict of interest regarding the publication of this article.

\section{References}

1. World Health Organization. A global brief hypertension: Silent killer, global public health disease. WHO Press: Switzerland; 2012.

2. Marković BB, Kranjčević K, StojanovićŠpehar S, Blažeković-Milaković S, Kern J, Botica MV, et al. Treatment of hypertension by general practitioners and hypertensive drugs expenditure in an urban environment. Coll Antropol. 2009; 33(1):71-6.

3. Department of Health Republic Indonesia. Basic health research (Riskesdas) 2013 [Accessed on: $4^{\text {th }}$ September 2016]. Available at: http://www.litbang.depkes.go.id

4. Department of Health Republic Indonesia. Health profile of Banyumas Regency in 2014 [Accessed on: 11 $1^{\text {th }}$ October 2016] Availabe at: http://www.depkes.go.id/resou rces/download/profil/PROFIL_KAB_ KOTA_2014/3302_Jateng_Kab_Banyu mas_2014.pdf 2014 .

5. Mahjoob M, Nejati J, Hosseini A,
Bakhshani NM. The effect of Holy Quran voice on mental health. J Religion Health. 2014;55(1):38-42. doi: 10.1007/s10943014-9821-

6. Puspitasari HP, Aslani P, Krass I. A review of counseling practices on prescription medicines in community pharmacies. Rese Soc Adm Pharm. 2009;5(3):197210. doi: 10.1016/j.sapharm.2008.08.006.

7. Dahlan S. Statistics for medicine and health: Descriptive, bivariate, and multivariate, equipped with applications using SPSS. Jakarta: Salemba Medika; 2008.

8. Mottaghi ME, Esmaili R, Rohani Z. Effect of Quran recitation on the level of anxiety in athletics. Quarterly of Quran \& Medicine. 2011;1(1):1-4.

9. Copstead LC, Jacquelyn LB. Pathophisiology. Missouri: Elsevier Saunders; 2005.

10. Sugiharto A. Risk factors of grade II hypertension in the community [Accessed on: $10^{\text {th }}$ April 2017]. Availabe at: http:// eprints.undip.ac.id/16523/1/

11. Sudarno, Rusgiyono A, Hoyyi A, Listifadah. Quality services analysis and quality control services based on visitor perception. Media Statistik. 2011;4(1):33 $-45$.

12. Pratama TA, Rahman T, Rahman N. Analysis of consumer satisfaction food bar Subang regency. Proceedings of National Seminar on Research and PKM of Science, Technology and Health. Bandung: Universitas Islam Bandung: 2011:2089-3582. 